ISSN 0258-7122

Bangladesh J. Agril. Res. 34(3) : 343-350, September 2009

\title{
GLIRICIDIA LEAVES DECOMPOSITION: THE EFFECT OF PARTICLE SIZE ON MICROBIAL RESPIRATION
}

\author{
B.C. WALPOLA*, K.K.I.U. ARUNA KUMARA \\ A.P. SENANAYAKE AND S.D. WANNIARACHCHI
}

\begin{abstract}
Legume leaves used as green manure are a potential alternative to commercial fertilizers for non-legume crop production. Therefore, many researches have been conducted to understand the pattern of legume leaf decomposition and its release of nutrients. A study on Gliricidia leaves decomposition was conducted under laboratory conditions to elucidate the effect of grinding size of Gliricidia leaves $\left(S_{1}=\leq 0.5 \mathrm{~mm}, S_{2}=4 \mathrm{~mm}\right.$, and $\left.S_{3}=9 \mathrm{~mm}\right)$ on microbial respiration and $\mathrm{N}$ mineralization after incorporation in to the soil.

The early stages of the incubation were found to be significantly influenced by the particle size of the Gliricidia leaves. Particle size $\mathrm{S}_{2}(4 \mathrm{~mm})$ was reported to exhibit the highest $\mathrm{C}$ and $\mathrm{NH}_{4}{ }^{+}-\mathrm{N}$ mineralization. However, in the case of $\mathrm{NO}_{3}{ }^{+}-\mathrm{N}$ mineralization, no treatment was found to be significant. It could thus be hypothesized that physical protection of finely ground $(<0.5 \mathrm{~mm})$ Gliricidia leaves was responsible for the relatively low rates of decomposition.
\end{abstract}

Key Words: Decomposition, mineralization, Gliricidia leaves.

\section{Introduction}

As soil organic matter is easily oxidized under tropical conditions, its replenishment is of prime importance to avoid soil erosion which leads to the loss of its fertility (Krishnamurthy, 1978). Use of green manure could reduce soil exposure to the erosive processes, promote great nutrient cycling and improve the synchrony of nutrient release with crop demand (Cobo et al., 2002). Crop residue decomposition and subsequent release of nutrients to soil can be altered by a number of factors, including nutrient and water availability, soil temperature, physical and chemical nature of the crop residue and their amount, soil type and soil residue contact. The particle size, toughness, surface properties, such as cuticle thickness and composition, presence of' defense structures, etc. could be considered as the vital physical properties of the plant material (Swift et al., 1979). These properties have the potential to affect the accessibility of substrate to soil organisms, and thus alter the rate of colonization and patterns of decomposition and mineralization (Bending and Turner, 1999). A varied effect of the particle size of crop residue on decomposition and nutrient release dynamics after incorporation into the soil has often been reported in the literature (Sims and

\footnotetext{
* Department of Soil Science, Faculty of Agriculture, University of Ruhuna, Mapalana, Kamburupitiya, Sri Lanka.
} 
Frederick, 1970; Bending and Turner, 1999; Swift et al., 1979). Some studies have confirmed that particle size affects adversely on above processes (Sims and Frederick, 1970; Nyhan, 1975; Amato et al., 1984), while other investigations have shown the reverse effect (Stickler and Frederick, 1959; Jenson, 1994; Sorenson et al., 1996).

Farmers in developing countries cannot afford inorganic fertilizers. The detrimental effect of long-term use of inorganic fertilizers is well known. Legume leaves used as green manure are a potential alternative to the use of commercial fertilizers for non-legume crop production. Organic farming is now preferred throughout the world for improving soil properties and environment. Now-a-days, many researches are conducting to understand the pattern of legume leaf decomposition and its release of nutrients. Decomposition and mineralization of plant material incorporated into soil reflects interaction between its quality and prevailing chemical and physical environment of soil. Many studies have attempted to relate biochemical quality to decomposition and mineralization and much less are known of the way in which physical quality affects mineralization. Among the quality parameters, particle size of the crop residues have confirmed that it affects the above processes. Some researchers reported that reducing particle size increases rates of microbial processors, while others reported reverse effect. Thus, it is important to assess these contrasting results furthermore. Therefore, the present study was undertaken

- to investigate the effect of particle size on microbial activities during decomposition of Gliricidia leaves.

- to determine the pattern of nutrient release ( $\mathrm{N}$ \& $\mathrm{P}$ ) during the decomposition of various sized particles of the Gliricidia leaves.

\section{Materials and Method}

\section{Climate and soil}

The experiment was conducted at the Faculty of Agriculture, University of Ruhuna, Mapalana, Kamburupitiya, Sri Lanka. According to the agro-ecological classification (Panabokke, 1980), the region of investigation comes under agroecological region $\mathrm{WL}_{2}$ (low country wet zone). The soil used in this study belongs to Red Yellow Podzolic great soil group and is classified as Hapludults according to the USDA soil taxonomy (Mapa et al., 1999). The climate of the area is tropical monsoonal (Panabokke, 1980), with a warm wet period (April to June) arid a relatively dry period (January to March). The area receives an annual rainfall of around $2500 \mathrm{~mm}$. The distribution of rain is bi-model. Annual mean air temperature of the area is $22-30^{\circ} \mathrm{C}$ and the relative humidity is about $80 \%$. 


\section{Soil sampling}

Soil samples were collected randomly from several selected locations at the research farm of Faculty of Agriculture, University of Ruhuna, Mapalana, Kamburupitiya, Sri Lanka. After removing the surface litter, soil samples were taken from $0-15 \mathrm{~cm}$ depth by using an auger. They were then mixed thoroughly in order to make a composite sample. Physico-chemical characteristics of the soil were determined using standard methods. Soil kept in glass bottles was preincubated for a week at $60 \%$ water holding capacity prior to the treatments.

\section{Treatments}

Leaves of the Gliriciclia were collected, oven dried $\left(60^{\circ} \mathrm{C}\right)$ and ground to the size of $S_{1}=\leq 0.5 \mathrm{~mm}, S_{2}=4 \mathrm{~mm}$, and $S_{3}=9 \mathrm{~mm}$. Sub samples of $100 \mathrm{~g}$ of homogeneously mixed air dried soil were placed in glass bottles. Bottles were watered to adjust the moisture content to $50 \%$ of the field capacity (dry basis) and maintained by daily monitoring and adding water when necessary. Bottles were then kept in dark for two weeks prior to addition of plant materials. After two-week pre-incubation period, the glass bottles were opened and $235 \mathrm{mg}$ of various sized particles of the leaves were mixed thoroughly with the soil. This was a mulch application rate equivalent to 5 tons dry matter per hectare, on the assumption that 1 ha of soil $15 \mathrm{~cm}$ deep contains $2.13 \times 10^{9} \mathrm{~kg}$ of soil (bulk density of the soil $1.42 \mathrm{~g} / \mathrm{cm}^{2}$ ). Treated soil samples along with the controls (free from plant materials) were then incubated in the dark at room temperature $(25 \pm$ $\left.1{ }^{\circ} \mathrm{C}\right)$. Constant moisture content of the soil was maintained throughout the incubation period.

\section{Carbon mineralization}

Soil samples were placed in gas-tight glass containers along with a vial containing $10 \mathrm{ml}$ of $1 \mathrm{M} \mathrm{NaOH}$ to trap $\mathrm{CO}_{2}$ and a vial of water to maintain humidity. Soil was incubated at room temperature $\left(25^{\circ} \mathrm{C}\right)$ in the dark and $\mathrm{NaOH}$ traps were replaced at $2,5,7,14,21,28,35,42,49,56,63$, and 70 days after the treatment. Unreacted alkali in the $\mathrm{NaOH}$ traps was titrated with $0.5 \mathrm{M}$ HCI to delermine $\mathrm{CO}_{2}-\mathrm{C}$ released from the soil (Anderson, 1982).

\section{Nitrogen mineralization}

$\mathrm{N}$ mineralization was determined using inorganic $\mathrm{N}\left(\mathrm{NH}_{4}{ }^{+}-\mathrm{N}\right.$ and $\left.\mathrm{NO}_{3}{ }^{-} \mathrm{-}\right)$ concentration of soil extracted at 2, 5, 7, 14, 21, 28, 35, 42, 49, 56, 63, and 70 days after the treatment. Samples containing $10 \mathrm{~g}$ of soil, were extracted using 30 $\mathrm{ml}$ of $2 \mathrm{MKCI}$ and extracts was used to determine $\mathrm{NH}_{4}{ }^{+}-\mathrm{N}$ and $\mathrm{NO}_{3}{ }^{+}-\mathrm{N}$. $\mathrm{NH}_{4}{ }^{+}-\mathrm{N}$ was determined utilizing the Berthelot reaction (Searle. 1984) and $\mathrm{NO}_{3}{ }^{-}-\mathrm{N}$ was determined by utilizing the sodium salicylate yellow colour method (Bremner, 1960). 


\section{Statistical analysis}

Data generated were subjected to analysis of variance (ANOVA) for a Completely Randomized Design (CR1)) with four replicates using SAS software (SAS Institute, 1988). Least significant difference at $\mathrm{P} \leq 0.05$ was used to separate the means.

\section{Results and Discussion}

The effect of particle size of the Gliricidia leaves on carbon mineralization in soil is depicted in Figure 1. Carbon mineralization of the soil was found to reach the peak at day 14 followed by gradual reductions in all the treatments as incubation progressed. At day 5 of the incubation, $\mathrm{S}_{1}$ had no significant $(\mathrm{P} \leq 0.05)$ effect on carbon mineralization, while $S_{2}$ and $S_{3}$ were shown to have higher carbon mineralization than that of in $\mathrm{S}_{1}$. Thereafter no significant $(\mathrm{P} \leq 0.05)$ differences in carbon mineralization were observed among the treatments until day 35. After 35 days of incubation, fine particles $(\leq 0.5 \mathrm{~mm})$ inoculated soils showed significantly $(\mathrm{P} \leq 0.05)$ higher carbon mineralization than the $\mathrm{S}_{3}$ inoculated soils.
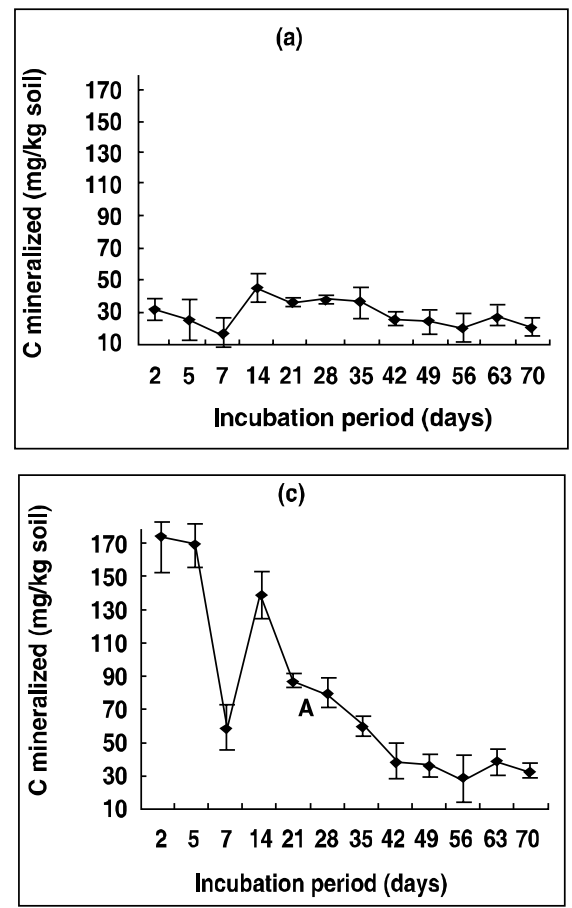

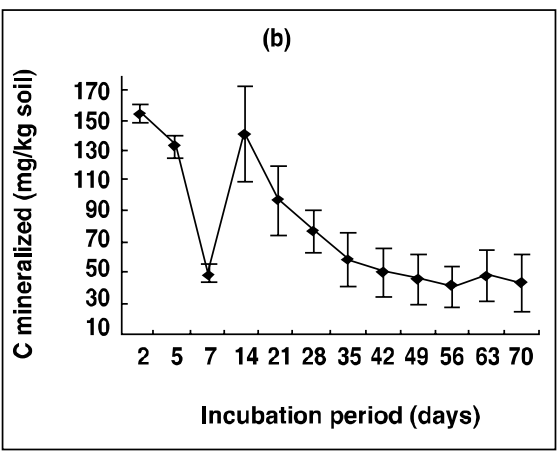

(d)

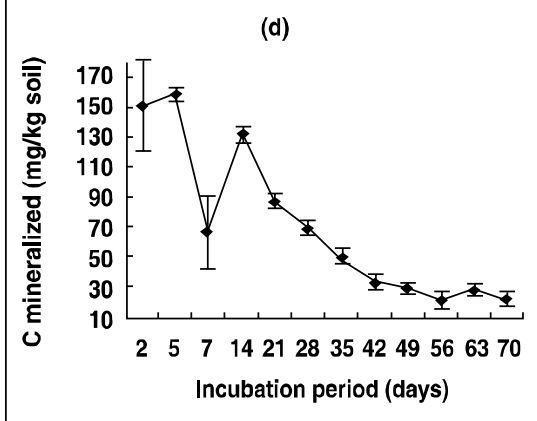

Fig. 1. Carbon mineralization of the soil amended with various sized particles of Gliricidia leaves. (a) Control (without Gliricidia leaves), (b), (c) and (d) represent particle sizes $\leq 0.5,4$, and $9 \mathrm{~mm}$, respectively. Values given here are the means $(n=4)=$ standard deviation. 
Figure 2 shows the cumulative $\mathrm{C}_{2}-\mathrm{C}(\mathrm{mg} / \mathrm{kg}$ soil) evolution of the soil amended with various sized particles of Gliricidia leaves. Cumulative $\mathrm{CO}_{2}-\mathrm{C}$ content was not significantly $(\mathrm{P} \leq 0.05)$ affected by the particle size of Gliricidia leaves (Fig. 2). However, treatment $S_{2}$ showed the higher values.

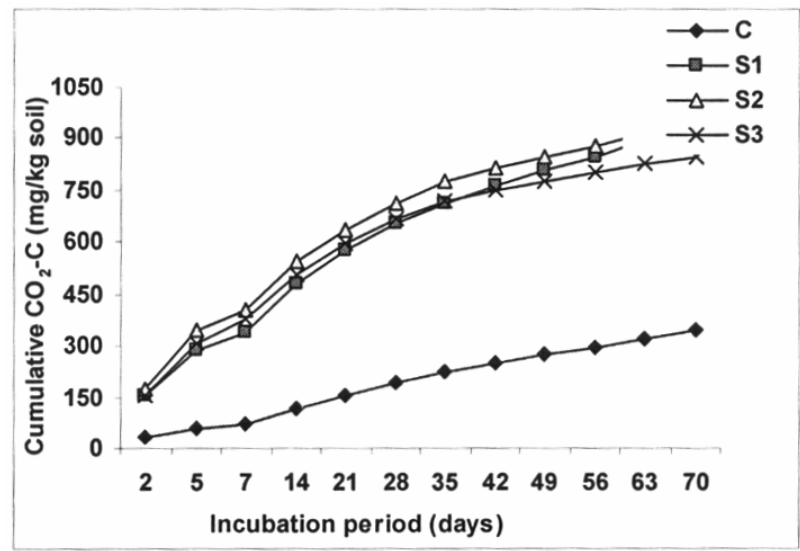

Fig. 2. Cumulative $\mathrm{CO}_{2}-\mathrm{C}(\mathrm{mg} / \mathrm{kg}$ soil $)$ evolution of the soil amended with various sized particles of Gliricidia leaves $\left(\mathrm{C}=\right.$ control soil. $\mathrm{S}_{1}=\leq 0.5$ $\mathrm{mm}, \mathrm{S}_{2}=4 \mathrm{~mm}$ and $5_{3}=9 \mathrm{~mm}$ ).
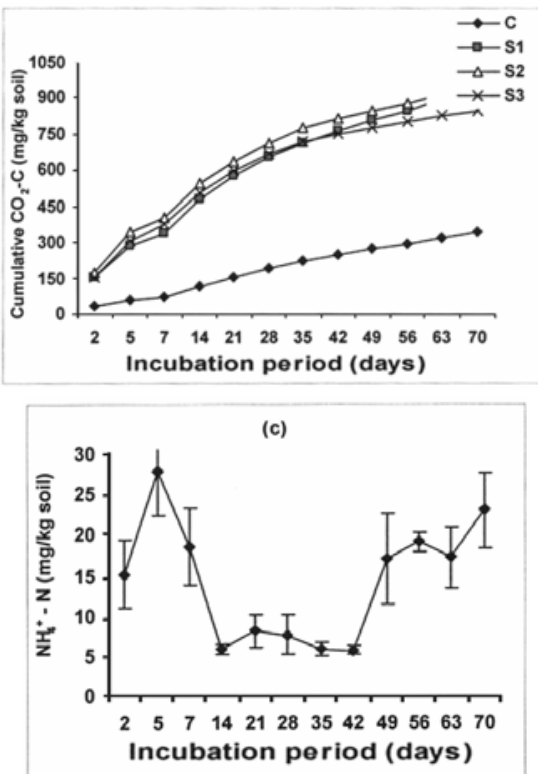

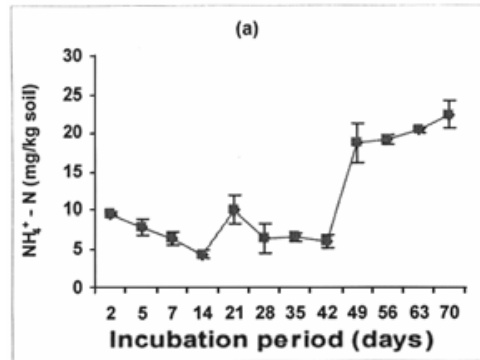

(d)

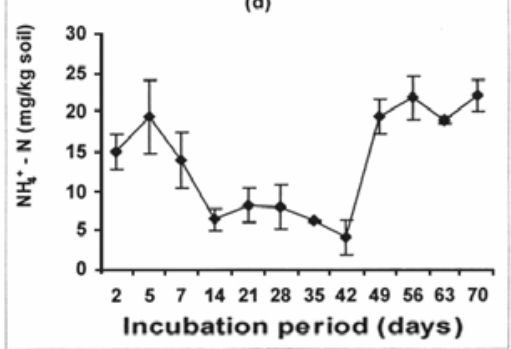

Fig. 3. Release ol $\mathrm{NH}_{4}{ }^{+}-\mathrm{N}$ from the soils amended with various sized particles of the Gliricidia leaves. (a) Control (without Gliricidia leaves), (b), (c) and (d) represent particle sizes $\leq 0.5,4$, and $9 \mathrm{~mm}$, respectively. Values given here are the means $(n=4) \pm$ standard deviation. 
The effect of particle size of Gliricidia leaves on nitrogen mineralization in soil is shown in Figures 3 and 4. Intermediate sized particles $\left(\mathrm{S}_{2}=4 \mathrm{~mm}\right)$ were found to exhibit the highest $\mathrm{NH}_{4}{ }^{+}-\mathrm{N}$ content during the first seven days of the incubation followed by larger sized particles $\left(\mathrm{S}_{3}=9 \mathrm{~mm}\right)$ (Fig. 3). A possible reason for the decreasing trend of $\mathrm{NH}_{4}{ }^{+}-\mathrm{N}$ content during the period of day 5 to 14 may be due to the immobilization or nitrification. After 14 days of the incubation, $\mathrm{NH}_{4}{ }^{+}-\mathrm{N}$ content of the soil was found to be almost equal in all the treatments including the control soil until 42 days. Despite no significant differences were observed, nitrogen mineralization was proved to be increased in all the treatments during the final few days of the incubation.

Results revealed that $\mathrm{NO}_{3}-\mathrm{N}$ content in all the treatments increased throughout the incubation period except control (Fig. 4). However, the releasing pattern of $\mathrm{NO}_{3}-\mathrm{N}$ seemed to be complex.
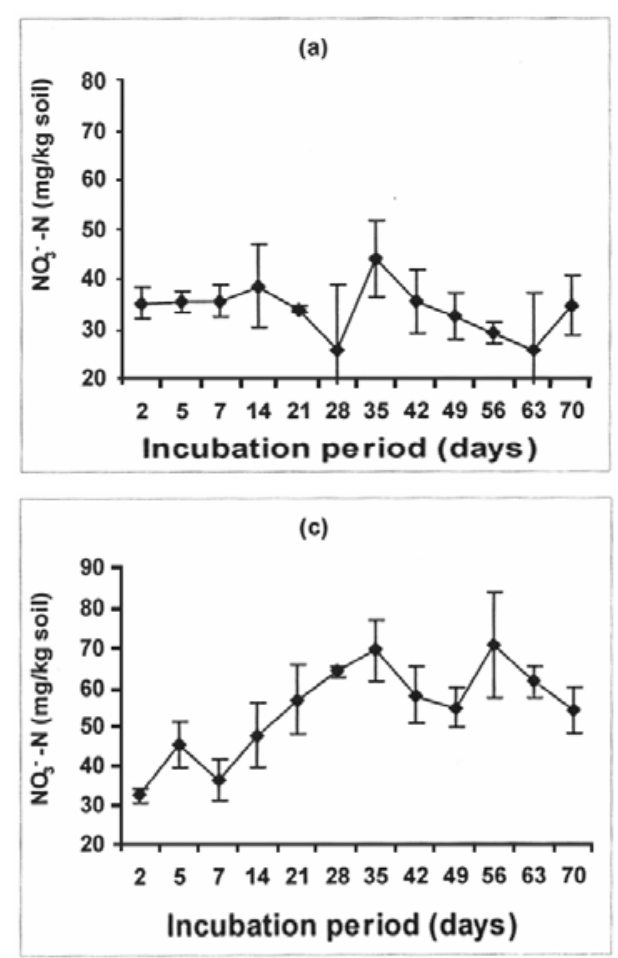

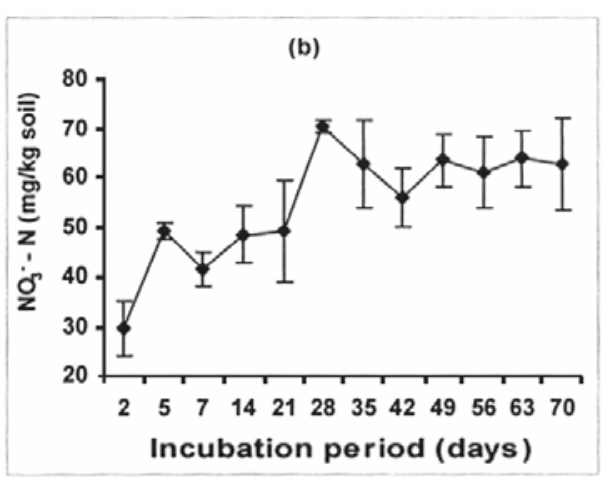

(d)

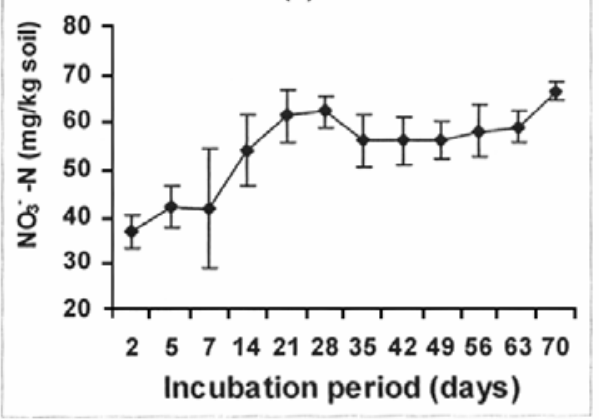

Fig. 4. Release of $\mathrm{NO}_{3}{ }^{-}-\mathrm{N}$ from the soils amended with various sized particles of the Gliricidia leaves. (a) Control (without Gliricidia leaves). (b), (c) and (d) represent particle sizes $\leq 0.5,4$, and $9 \mathrm{~mm}$, respectively.

The present findings are in agreement with Sims and Frederick (1970), who also observed a reduction in $\mathrm{C}$ mineralization due to reduced particle size of canola residues. This may be due to lack of enough adsorptive surfaces offered by the small proportion of clay and silt content in the soil. Larger particles, on the 
other hand, showed higher cumulative $\mathrm{C}_{2}-\mathrm{C}$ evolution, which may be due to their greater distribution in the soil ensuring a greater accessibility to microbial attack (Sims and Frederick, 1970).

According to the Swift et al. (1979), particle size of the crop residues influence the activities of microbial population in soil and the stages of the decomposition. Particle size controls the surface area available for the colonization of the soil microbes and will influence the exchange of water, nutrients, and oxygen. Thus, decreasing particle size increases the specific surface area and speed up the colonization. It leads to rapid mineralization with the decreasing size of the particle.

On the other hand, particle size influences the contact of the material with clay and silt particles, which can act to protect organic materials from microbial attack. It leads with decreasing size of the particles (Hassink, 1997). The present results demonstrate the slower decomposition of finer particles at the early stages. Reason may be the physical protection of decomposing organic matter by clay and silt particles.

\section{Conclusion}

The present results revealed that carbon and nitrogen mineralization of Gliricidia leaves were affected by the particle size. They could also be affected by the texture of the soil. The soil used in this study was loamy sand in texture, so physical protection of decomposing organic matter would be small in this soil.

\section{References}

Amato, Nt and J. N. Ladd. 1988. Assay for microbial biomass based on ninhydrinreactive nitrogen in extracts of fumigated soils. Soil Biol. Biochem. 20: 107-114.

Bending, G. D. and M. K. Turner. 1999. Interaction of biochemical quality and particle size of crop residues and its effect on the microbial biomass and nitrogen dynamics following incorporation into soil. Biol. Fertil. Soils 29: 319-327.

Bremner, J. M. and C. S. Mulvaney. 1982. Total nitrogen. In. A.l..Page (ed) Methods of Soil Analysis. Part 2. Chemical and Microbiological Methods. 2nd Edition. Amer. Soc. Agron. pp. 1149-1178.

Cob, J. G, E. Burrios, D. C. L. Kass and R. J. Thomas. 2002. Decomposition and nutrient release by green manures in tropical hillside agro-ccosystem. Plant Soil 23: 331-342.

Hassink, J. 1997. The capacity of soils to preserve organic C and $\mathrm{N}$ by their association with clay and silt particles. Plant Soil 191: 77-87.

Jensen, E. S. 1994. Mineralization -immobilization of nitrogen in soil amended with low C: ratio plant residues with different particle sizes. Soil Biochem. 26: 519-521.

Krishnamurthy, R. 1978. A manual of compost and other organic manure. Today and Tommorow's Printers \& Publishers. pp. 85-119. 
Mapa. R. B., S. Somssiri and S. Nagarajah. 1999. Soils of the wet zone of Sri Lanka. Soil Sci Soc. SL. Sri Lanka. pp. 23-92.

Nyhan, J. W. 1975. Decomposition of carbon ${ }^{-14}$ labelled plant materials in a grassland soil under field conditions. Soil Sci Soc Am. J. 39: 643-648.

Panabokke, C. R. 1980. Handbook of the soils of Sri Lanka. J. Soil Sci. Soc. 2: 83-85.

SAS Institute. 1988. SAS/STAT user's guide, Release 6.03. SAS Institute, Cary, North Carolina, USA.

Searle, P.L. 1984. The Berthelot or indophenol reaction and its use in the analytical chemistry of nitrogen: a review Analyst 109: 549-568.

Sims, J. L. and L. R. Frederick. 1970. Nitrogen immobilization and decomposition of corn residue in soil and sand as affected by residue particle size. Soil Sci. 109: 355361

Sorenson, P., J. N. Ladd and M. Amato. 1996. Microbial assimilation of ${ }^{14} \mathrm{C}$ of ground and unground plant materials decomposing in a loamy sand and a clay soil. Soil Biol. Blochem. 28: 1425-1434

Sticker, F. C. and I. R. Frederick. 1959. Residue particle size as a factor in nitrate release from legume tops and roots. Agron. J. 51: 271-274

Swift. M. J., 0. W. Heal and J. M. Anderson. 1979. Decomposition in terrestrial ecosystem. Blackwell, Oxford. 